\title{
The 'new' discourse of the Front National under Marine Le Pen: A slight change with a big impact
}

European Journal of Communication

(C) The Author(s) 2016 Reprints and permissions: sagepub.co.uk/journalsPermissions.nav DOI: I0.1 I77/0267323 I I6680I32 ejc.sagepub.com

@SAGE

\author{
Daniel Stockemer \\ University of Ottawa, Canada
}

\section{Mauro Barisione}

Università degli Studi di Milano, Italy

\begin{abstract}
In recent years, the Front National, under the leadership of Marine Le Pen, has experienced a political revival. In elections, membership numbers and public opinion polls, the party has made impressive gains. We argue in this article that these gains stem, at least in part, from a strategic repositioning of the party based on a more populist discourse and communication style. Through a content analysis of posts (press releases) on the party's Facebook page from 2013 to 20I5, we first highlight that, besides giving the Front National a more presentable image, Marine Le Pen has changed the Front National on two fronts: (I) she has rendered the party's discourse more populist and (2) she has managed to reframe the party's leitmotif of immigration. Second, through quantitative analysis of 'Likes' for each post, we find that this new discourse resonates well with Front National sympathizers.
\end{abstract}

\section{Keywords}

Methodology, political communication, populism, social media

\section{Introduction}

Since Marine Le Pen took over the presidency of the Front National (FN) from her father Jean Marie Le Pen in January 2011, this radical right-wing party has been

\footnotetext{
Corresponding author:

Mauro Barisione, Department of Social and Political Sciences, Università degli Studi di Milano,

Via Conservatorio 7, 20122 Milano, Italy.

Email: mauro.barisione@unimi.it
} 
successful on three fronts: membership (an increase from 22,000 members in January 2011 to 83,000 members in December 2014 (Le Figaro, 2014)), electoral success (in the 2014 and 2015 European, departmental and regional elections, the party recorded its best results ever, winning $24.9 \%, 25.2 \%$ and $27.7 \%$ of the popular vote, respectively) and public opinion (e.g. opinion polls show that the percentage of individuals who consider the FN a 'danger' decreased by nearly 20 percentage points from $70 \%$ to $50 \%$ between 2002 and 2012). ${ }^{1}$

How has this unprecedented success been possible? Recent studies have explained the resurgence of the FN in terms of structural conditions such as immigration (e.g. Della Posta, 2013), or the economic crisis (Hewlett, 2012) or changes in the electorate (Mayer, 2013). In this study, we focus on the party's discourse, which we define as a combination of stylistic, rhetorical and ideological elements. Using a 'supply and demand' framework, we argue that subtle changes in the party's discourse (e.g. the renewed populist focus and a reframing of the party's leitmotif immigration) have helped the FN to attract renewed support and to consolidate the backing of old sympathizers. We conduct our argument in two steps. First, using official party documents and press releases, we highlight the (subtle) changes in the party's discourse from Le Pen father to Le Pen daughter. Second, by analysing more than $350 \mathrm{FN}$ press releases posted on the official FN France Facebook page and the 'Likes' for any of these postings or press releases, we test whether the FN's new communication resonates well with the party's members and supporters.

This article proceeds as follows: In the next section, we briefly explain the theoretical and methodological framework adopted for our research. In the third part, we analyse the FN's political discourse under Jean Marie Le Pen and Marine Le Pen, and evidence the subtle rhetorical changes that the party has adopted under Marine Le Pen. Finally, by analysing FN Facebook postings and readers' reactions, we find that this 'renewed FN discourse' has a clear positive impact on the party's supporters.

\section{Theoretical and methodological framework}

The success of a social group or party depends heavily on its capacity to respond to activists' demands for action. To explain this relationship, the social psychological literature on social movement and party activism (e.g. Klandermans, 1997, 2004) has introduced the supply and demand metaphor. As in the realm of political marketing (Newman, 1999; Schumpeter, 1942), this metaphor compares party elites to entrepreneurs and activists to consumers in the free market economy. In the original metaphor, demand refers to the potential buyers of a product, whereas supply stands for the entrepreneurs' capacity to meet that demand. For a company to be successful, it must either match the demand for a certain product or create some desire for that specific product. Applied to party activism, this implies that 'a demand for populist radical right politics does not necessarily result in the emergence of such a party and its success at the party system level' (Mudde, 2007: 202). Rather, the political standing and success of these parties hinge upon the capabilities and choices of these groups and their leaders (Kitschelt, 1995). In other words, the more the right-wing party is successful, the more it can convince members and recruits that activism is worthwhile and necessary. Most importantly, parties like the FN must use convincing ideological frames and conditions; both old members and new 
recruits must be convinced by the party's values and beliefs and must see the necessity of engagement (van Stekelenburg and Klandermans, 2007).

To convince the masses, the FN (and other radical right-wing parties in Europe) try to foster popular persuasion and mobilization with the help of a 'populist discourse' which combines elements from both a populist 'ideology' and a populist communication 'style' (Aalberg et al., 2016). The ideational component essentially rests on a 'combination of people-centrism and anti-elitism' (Rooduijn et al., 2014: 567; see also Albertazzi and McDonnell, 2008; Canovan, 1999; Mudde, 2007) and on the exclusion of specific population categories (e.g. most typically, immigrants) from the community of people, considered as a homogeneous body (Abts and Rummens, 2007; Betz and Immerfall, 1998). Conversely, the stylistic dimension, which 'has been largely overlooked even though populist politics is a well-documented feature of many European democracies and has attracted much attention' (COST, 2013: 1), comprises the use of simple and strong language (Bos et al., 2011; Taggart, 2000): a language that is 'slogan-based, tabloid style' (Mazzoleni, 2003: 5) and which employs not only continuous references to 'the people' (Jagers and Walgrave, 2007) but also a strong charismatic party leadership (Alvares and Dahlgren, 2016; Bos et al., 2011; Mudde and Kaltwasser, 2014; Plasser and Ulram, 2003) and messages that assign blame to elites in an 'emotionalized way' (Hameleers et al., 2016).

Rather than artificially separating the ideological and the communication-based elements, we maintain that 'stylistic and ideological populism [ ... tend to converge' (Krämer, 2014: 46). In effect, we assume that a 'populist discourse' combines ideological and stylistic elements with effects of mutual reinforcement. Even more importantly, when a populist discourse is emphasized, the radical right component is obscured in terms of presentation but not necessarily in its content. Operationally, to detect a higher degree of populism - or populist discourse - among the new FN elites, we first expect to find within FN documents and press releases a straightforward and emotional language, frequent antielite claims and statements made 'in the name of the people'. Second, we expect to find communications that are less party-centred and more personalized - that is, focused on the party leader as a person - and which, in turn, emphasize the 'charismatic' relationship between the leader and the party supporters. Because the creation of a synergy between the ordinary people and the charismatic leader is a fundamental trait of the classic notion of charisma (Weber, 1968 [1922]), and given that only populist leaders can aspire to be recognized as genuinely charismatic (Barisione, 2016), populist actors should typically address followers in terms of 'us' - that is, the leader with the masses. The use of 'us' should prevail not only over mentions of 'party' as such but also over mentions of 'me', which removes the charismatic relationship between the leader and followers. Finally, we expect to find anti-immigrant appeals that are framed in populist and pseudo-democratic terms - that is, reflecting the economic interests of ordinary citizens and/or blaming the political elites for their policies - rather than in 'biologically' racist terms. Overall, these elements compose what we describe as a 'populist discourse'. 2

In what follows, we show that a populist reshaping of the party's message has rendered the new FN under Marine Le Pen more attractive to sympathizers, members and potential recruits than the 'old' FN under Jean Marie Le Pen. To do so, we engage in a two-step analysis. Using party documents, we first juxtapose the party's programme under Jean Marie Le Pen with current FN programmes, the purpose being to underline 
the changes on the supply side offered by the new FN leadership. ${ }^{3}$ Second, we use the social media platform Facebook to test the hypothesis that representatives (e.g. Marine Le Pen and Louis Aliot) of the new FN image, which is more 'populist' than 'radical right' and which aims to address the problems of everyday citizens, gain more online support than Facebook posts of the old elite (e.g. Jean Marie Le Pen and Bruno Gollnisch).

In order to determine the degree to which the new image of the FN resonates better than the old image among members, supporters and sympathizers, we engage in a novel analysis which takes advantage of the fact that activism takes place as much online as offline (Dahlgren, 2013). As it was for the party website at the dawn of the digital age (Atton, 2006; Bratten, 2005; Dézé, 2011), social media is now one of the most, if not the most, important platform for parties like the FN to broadcast their message (Elinas, 2014). Digital social networks such as Facebook or Twitter are hubs for online activism (Karpf, 2012); they enable parties to communicate with their members and the wider public. In the words of Bartlett et al. (2011), there is a shift in how political support in favour of parties like the FN is expressed: formal party membership numbers are often dwarfed by thousands of online supporters on Facebook and other social media websites. To highlight this point, Bojadjian (2015: 151) shows that the FN has the most Facebook fans of all parties (as of 5 May 2015, the FN has 224,079 supporters, which is nearly double the number of the second-placed party, the Republicans (former Union for Popular Movement (UMP)), with 121,217 supporters). In addition, especially proponents of a non-mainstream ideology can find online what they are looking for: a nonmainstream and alternative interpretation of society and the world around them. Therefore, for the purpose of this study, we maintain that sympathizers' reactions to these Facebook postings can provide a rather accurate picture of FN supporters' preferences and their demands for action (for a similar claim in relation to Twitter, see Ceron et al., 2014).

\section{The old FN under Jean Marie Le Pen and the new FN under Marine Le Pen}

At first glance, there is little difference between the ideology of the old FN under Jean Marie and that of the new FN under Marine Le Pen. For over 40 years, the FN has advocated a simplistic 'master frame' (Benford and Snow, 2000) that pushes anti-immigrant, anti-establishment and nationalist sentiments. As such, the FN portrays French society as tainted by foreign influences and governed by corrupt elites which embrace lax government policies in the area of public security (Crépon, 2012). The FN embeds these vices in an ethnocentric worldview, a worldview which argues that the nation should be primarily reserved for people of a certain type: individuals who share the same ethnicity, history, religion and identity (Hainsworth, 2008: 12).

In practice, this ethnocentric worldview translates into a political discourse that advances anti-foreigner and anti-immigrant positions often linked to unemployment, public insecurity and welfare chauvinism (i.e. social programmes should work to the exclusive benefit of a nation's 'own' people (see Eatwell, 2000: 413)). However, there are also changes in the popular rhetoric between Le Pen father and daughter. While it is true that throughout its history the FN has always played with a populist message (e.g. as 
early as the presidential election of 1984, Jean Marie Le Pen used the slogan 'Le Pen, Le Peuple' (Le Pen, The People) (DeClair, 1999: 81), populism was not always conspicuous in Jean Marie Le Pen's speeches and party platforms, in particular at the end of his reign as president. Rather than the populist, it was the radical element that prevailed, and which manifested itself in sometimes racist or anti-semitic statements (DeClair, 1999: 89; Kling, 2012: 68). In contrast, the FN under Marine Le Pen has replaced her father's radical statements with a populist but respectable rhetoric (see also Alduy and Wahnich, 2015). This difference in the degree of populism is visible in the two most recent presidential programmes. For example, Jean Marie Le Pen's 2007 electoral platform contained 69 pages, adopted a pseudo-scientific style, and presented numerous data and statistics. The tone was neutral, and there were no direct references to Jean Marie Le Pen. The main social bases of populist parties - the lower and middle classes - were not mentioned in a single sentence, there were no policy proposals with specifically populist connotations either, and the programme had very little of an anti-elite character. There were no references to the 'UMPS'4 or the fraudulent French elites. The word 'corruption' was not used even once. In fact, the document only had a somewhat anti-elitist tone when it criticized the international elites.

By contrast, Marine Le Pen's 2012 presidential programme contained all the components of populism as described above. First, it was not presented as a party programme but rather as Marine's 'personal' project, which presents Marine Le Pen as a 'crisis manager' and as a leader of the people who could rebuild France. This personification starts with the title of the programme: 'My Project, for France and for the French people' and 'Marine Le Pen, the voice of the people, the spirit of France'. Throughout the programme, it is Marine Le Pen, the charismatic leader, who is the focus of all attention. The programme contains 10 references to Marine Le Pen; by contrast, the FN was not mentioned at all. On several occasions, Marine Le Pen, the pure leader, also juxtaposed herself directly to the mainstream and 'crooked' parties of the establishment. For example on page 3 , the party platform states,

There are only two choices to make France competitive again: either to reduce wages and to dismantle the social protection system; this is the choice of the UMPs, or to act on our money and to refuse the drastic austerity plans: this is the choice of Marine Le Pen.

In this respect, the 2012 presidential programme is not presented as a party programme but rather as Marine's personal project.

As a second feature, Marine Le Pen's programme has a strong anti-elitist character. Marine Le Pen presents herself as the representative of the honest and hard-working people who not only faced unfair foreign competition but are also governed by corrupt political and social elites. For instance, the FN leader not only promises to stop the sumptuous expenses and excessive reimbursements of the party elites but she also identifies the lavish lifestyle of France's political elites as a major cause of France's debt crisis. She wants to do away with corruption, elite dominance and France's dependence on international organizations. Moreover, to portray a vision of decline and decay, Marine Le Pen uses simple and strong language: For example, the words 'rupture' or 'break up' to display her complete opposition to the system and the actors representing it. Similarly, the 
FN leader deliberately uses bellicose language (e.g. 'small neighborhood markets must be defended against multinational corporations' or 'social abuse will be combatted').

As a third and final feature of populism, Marine's programme directly addresses the masses. It is clear and simple, and only 16 pages long. The programme further addresses the common sense of the electorate and focuses on the main preoccupations of the popular classes, such as wages, purchasing power, and social and public security. In addition, the programme contains popular measures, including the rise in modest wages, the protection of France's economy against foreign influences and the reward of honest work. In sum, Marine Le Pen presents herself as an outsider to the political system and as an alternative political force promising to restore a genuine people's democracy on a nationalist basis.

\section{Results: Content analysis of Facebook posts and Likes}

To acquire more solid findings on the populist nature of the old and new FN, we carried out a quantitative content analysis of 355 press releases signed by 9 different members of the older versus newer party elite on the FN official Facebook page from October 2013 to October 2015. In this quantitative content analysis, which we conducted using the QDA Miner and Wordstat softwares for text analysis, we distinguished between the new elites (Marine Le Pen and her entourage - Nicolas Bay, Steeve Brios and Dominque Bilde) and the old elites (Jean Marie Le Pen and his entourage - Christine Arnautu, Bruno Gollnisch and Wallerand de Saint Juste). We did not include Jean Marie Pen`s granddaughter Marion Maréchal Le Pen in either of the two camps, because she is not clearly definable as belonging to either the old or new elite. To determine the degree of populism in the discourses of the two types of party elites, we looked at how each of these groups uses the main elements of a populist discourse, as we have described it in the theoretical and methodological framework, in their press releases. In more detail, we operationalized people centrism as the number of mentions of the words 'people' and 'French', whereas we covered the elite dimension by searching for the words 'betrayal', 'corruption', 'elites' and 'UMPS'. ${ }^{5}$ Moreover, we juxtaposed references to the party organization ('Front National') and to the first person 'me' (je) with more direct references to 'us' (nous) as a synthesis between the leader and the people.

The quantitative analysis of the 355 press releases confirmed our expectation, that is, the new FN under Marine Le Pen has become more populist in its discourse (see Figures 1 and 2). The new elites make references to 'we' (nous) almost twice as often as the old elites. Even more tellingly, the old leader Jean Marie Le Pen uses the personal pronoun 'me' in most of his press releases, whereas Marine uses 'us' three times more often than she uses 'me'. There are also many more references to the people and the French in the press releases of the new elites or Marine Le Pen. As regards anti-elitism, the new party elites in general and Marine Le Pen in more detail make more explicit references to 'UMPS', the 'elites' and 'corruption'. The exception to this rule is that the old elites (but not Jean Marie Le Pen) speak more of betrayal than do the new elites.

The following excerpt from a press release by Nicolas Bay exemplifies the populist nature of the new elite's discourse, which sometimes also has an epic dimension. Directly addressing the masses and party sympathizers, Nicolas Bay writes as follows: 


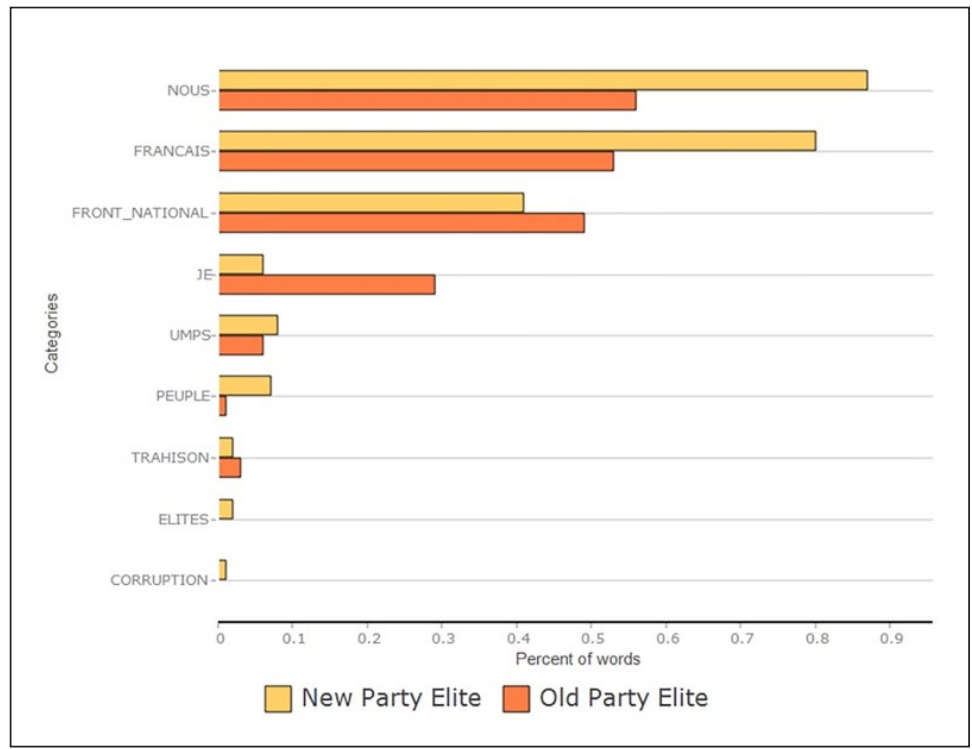

Figure I. Percentage of words referencing populism by type of party elite.

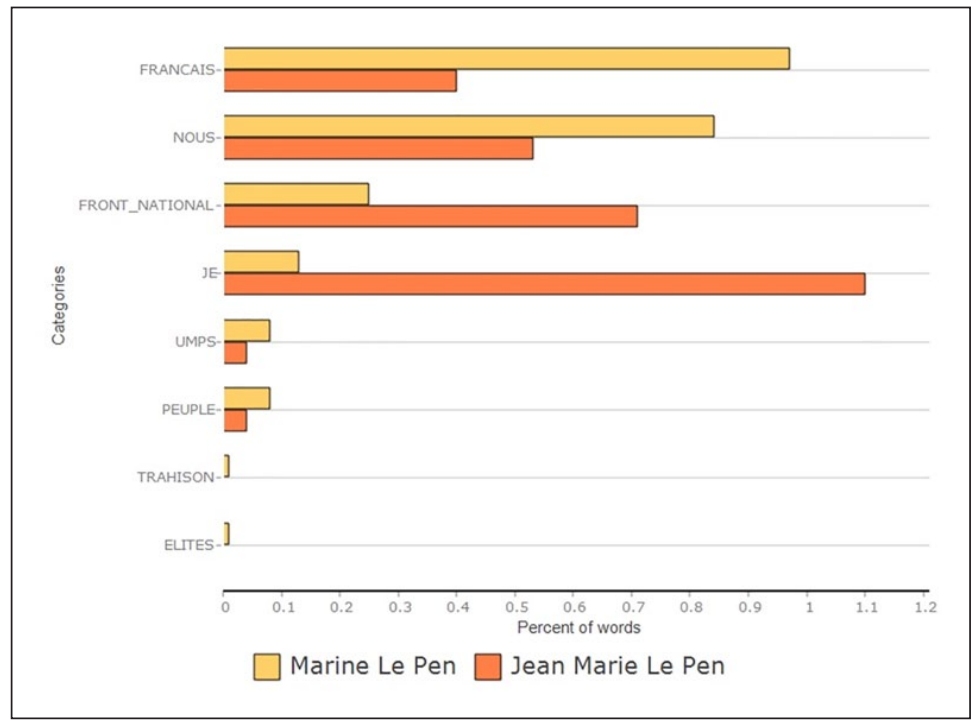

Figure 2. Percentage of words referencing populism: Jean Marie Le Pen versus Marine Le Pen.

Dear patriotic friends, we need to continue to fight hard locally so that next December the UMPS caste will be severely punished. The illegitimacy of the elites becomes more and more visible every day. If we fight with honor and perseverance against the propagandist machinery of Mr. Valls, our victory will even be greater and reach historic proportions. 


\section{Reframing immigration as the party's leitmotif}

Since the 1970s, (anti)-immigration has been the leitmotif of the FN's rhetoric, ideology and campaigns. Traditional slogans such as 'A million unemployed is a million immigrants too many! France and the French First', 'Defend our colors' or 'We are in France' have been used over and over again in speeches, press releases and campaigns (e.g. Bariller and Timmermans, 1993: 257). However, while the party's single most important issue - immigration - has remained the same under Marine Le Pen, the framing of the FN's anti-immigration discourse has changed. During most of Jean Marie Le Pen's presidency, anti-immigration or xenophobia was the central theme of the FN programme; all other policy areas were seen through an anti-immigration lens. In the 2007 party programme, the party first informed the French citizens of 'the facts about immigration'. For example, the first sentence in Jean Marie Le Pen's presidential programme in 2007 consisted of a blatant attack on immigration:

the costs of immigration are 60 billion Euros yearly, 70 percent of France's prison population is comprised of individuals of foreign origins, when counting legal and illegal immigrants, 95 percent of foreigners enter France without a work contract, and 50 percent of the beneficiaries of social welfare are foreigners. (Front National 2007: 2)

Preceding this introductory statement, the FN linked immigration to other policy areas, including public insecurity (e.g. 'the overrepresentation of immigrants in crime and criminality is a fact'), national identity (e.g. 'for France to remain France, the French people must remain masters in their own house'), social security ('immigrants (illegal and legal) are taking advantage of the social welfare system and other advantages that they 'cannot find in their home countries') and the labour market ('massive and uncontrolled immigration takes more than 1 million jobs away from the French and severely punishes our economy by imposing costs of over 300 billion francs').

In Marine Le Pen's 2012 presidential programme, immigration is not at the centre of the programme. Rather, anti-immigrant appeals are interwoven with the main concerns of large part of the French public, such as wages, purchasing power and social and public security. As such, the FN's anti-immigration platform is no longer presented as an end in itself but rather as part of a holistic solution; a solution which stresses that unemployment, social security and France's cultural and intellectual history can only be preserved if immigration is efficiently curbed. Discussed in the middle of the programme, the topic of immigration is strategically sandwiched between the party's economic platform, which is the FN's focal point, and social and cultural affairs. The measures proposed by the FN include the adoption of the national preference in public sector employment or the elimination of all pensions for foreigners who have not worked in France for at least 10 years.

The 355 documents that we analysed shed more detailed light on the strategic reframing of the party's leitmotif immigration. While immigration remains a highly referenced term in the FN's discourse across these press releases posted on the FN's Facebook page, the old party elites mainly frame immigration as a matter of security ('security' and 'insecurity' are the two terms most frequently co-occurring with the term 'immigration'). This type of frame is likely to be successful when crime and insecurity are the main 
concerns of national public opinion - typically as the result of a media agenda-setting effect (Burscher et al., 2015) - but not necessarily in other contexts. Conversely, the new elites manage to reframe 'massive immigration' (an expression occurring 31 times in their speeches) as the outcome of an irresponsible and lax European policy. Using a measure of the relative strength of co-occurrences between immigration and other words (i.e. the Jaccard similarity coefficient, which takes into account both the number of times that two words co-occur within the same paragraph and their overall frequency), we find that the new elites persistently link the immigration theme with the failure of the 'Schengen' zone (Jaccard $=0.120)$ and the absence of internal 'frontiers' $(0.121)$, and, more specifically, with the 'migration policy' $(0.108)$ implemented by the 'European Union' (0.124). They point to the 'consequences' $(0.126)$ of these policies in terms of growth of clandestins (illegal immigrants, 0.180) and increase in 'communitarianism' (0.134). This direct and repeated attribution of responsibility for the 'outburst' (explosion, 0.049) of immigration to the elite of EU policy-makers is very much absent in the old elite's press releases, in spite of the fact that the historical context is the same (20132015) for both groups. It is also telling that this new framing of the immigration theme, in addition to blaming the European elites and thus adopting a topos of the populist discourse, is done with a populist undertone. For example, the new elites use the metaphor 'migrant flood' (submersion migratoire) several times to decry the massive influx of immigrants. Similar rhetoric using strong images is less pronounced in Jean Marie and the old elite's speeches.

\section{A match of demand and supply: the popular success of a 'new' discourse}

To determine the extent to which the FN's new image resonates better than the old image among members, supporters and sympathizers, we evaluate followers' reactions to different types of press releases written by various types of individuals within the FN. To do so, we use a two-step analysis. We first present some descriptive statistics on the number of Likes. Second, we present the press releases with the most Likes by the old and new elites (i.e. we present all articles which received over 10,000 Likes), their authors and themes. We maintain that the number of 'Likes' that an article receives is a rather concrete indication of the actual appreciation of these articles by the readership, rather than being an indication of the amount of traffic on the FN Facebook page. For example, articles published on the same day may have a wide range of 'Likes' (e.g. three articles published on 4 August 2014 had 44, 1,400 and 11,925 Likes, respectively). Hence, the readers were actively looking at the articles but only liking those that resonated well with them. We also analyse the content of these articles qualitatively, the purpose being to evidence the topics and themes that readers appreciate the most. Second, we evaluate if there is a statistically significant and substantive difference in the number of 'Likes' postings received by the new generation of FN leaders (i.e. Marine Le Pen, Nicolas Bay, Steeve Brios and Dominique Bilde) with respect to postings by the old generation of FN leaders (e.g. Jean Marie Le Pen, Bruno Gollnisch, Wallerand de Saint Just and Christine Arnautu).

We find clear answers to our research questions. First, press releases by the new elite receive, on average, more than three times as many Likes as those by the old elites (see 
Table I. Average number of Likes by type of party elite.

\begin{tabular}{lrrr}
\hline & Mean & Standard deviation & $N$ \\
\hline Party elite (old) & 559 & 529.96 & 149 \\
Party elite (other) & 1310 & 821.55 & 28 \\
Party elite (new) & 2468 & 3810.24 & 178 \\
Total & 1576 & 2875.58 & 355 \\
\hline
\end{tabular}

Table 2. The 10 most 'Liked' articles.

\begin{tabular}{llll}
\hline Rank & Total Likes, $N$ & Author & Themes \\
\hline 1 & 16,882 & Marine Le Pen & Immigration, security \\
2 & 15,367 & Marine Le Pen & Nationalism, immigration, economy, EU \\
3 & 15,238 & $\begin{array}{l}\text { FN/Rassemblement } \\
\text { Bleu Marine }\end{array}$ & Security, religion \\
& & Nicolas Bay & Religion, nationalism, immigration \\
4 & 14,164 & Marine Le Pen & Economy, unemployment \\
5 & 13,380 & FN/Rassemblement & Immigration \\
6 & 11,670 & Bleu Marine & \\
7 & 10,692 & Marine Le Pen & Social security, nationalism \\
8 & 10,164 & Marine Le Pen & Economy, nationalism \\
9 & 10,076 & Marine Le pen & Economy, taxes \\
\hline
\end{tabular}

Table 3. OLS regression model (dependent variable= number of Likes per FB post).

\begin{tabular}{lc}
\hline Party elite (old) & 0.000 \\
Party elite (other) & $()$. \\
Party elite (new) & 572.334 \\
Year (20I3) & $(579.88)$ \\
& $1796.928^{* * *}$ \\
Year (20I4) & $(317.75)$ \\
& .000 \\
Year (20I5) & $()$. \\
Number of words & 324.634 \\
Intercept & $(380.07)$ \\
$N$ & $726.083+$ \\
Adj. $R^{2}$ & $(378.73)$ \\
P & -1.495 \\
\hline
\end{tabular}

OLS: ordinary least squares.

Significance levels: $+p<.1 ; * p<.05 ; * * p<.01 ; * * * p<.001$. 
Table 1). While the average number of Likes from the selected articles is 1579 (i.e. the most 'Likes' an article receives is 16,882 , whereas the lowest number is zero), the articles written by the new elites receive, on average, 2468 Likes compared to a meagre 559 Likes for the old elites. Marion Maréchal Le Pen, who stands ideologically between the old and the new elites, receives an amount of Likes that is exactly between those of the old and new elites. Her articles receive an average of 1310 Likes. On looking at the number of 'Likes', it is also evident that Marine Le Pen's postings are by far the most popular. As the charismatic leader, she is the face and the voice of the party, as well as the personification of the FN. As such, it is her postings and articles that receive the most attention. In contrast, Jean Marie Le Pen's articles receive seven times fewer 'Likes' (i.e. an average of 643 Likes per article vs. 4483 Likes per article). At first sight, the apparent lack of approval of the former FN leader seems odd, given that Jean Marie Le Pen shaped the FN for 40 years as president, face of the party and presidential candidate. However, at second sight, this apparent lack of enthusiasm for the former leaders' postings may stem from the fact that the FN has entered a new era: that of a young, dynamic, populist radical right-wing party which tries to present itself as a republican alternative to the mainstream political parties. The old Jean Marie Le Pen no longer fits this image.

Second, the most liked articles (i.e. all articles that received more than 10,000 Likes as of December 2015; Table 2) are also all written by the new elites (two of them under the banner Rassemblement Bleu Marine, which is Marine Le Pen's electoral coalition and thus linked to Marine Le Pen). Thematically, these most liked articles comprise all the features of the new FN. They are written in a populist style and adhere perfectly to a populist discourse: (1) they are clear, simple and short (7 of the 10 most liked articles are less than 300 words in length); (2) they use emotive writing with expressive punctuation to evoke the indignation of the reader (e.g. 'Europe colander desired by the UMPS'); (3) they have some anti-elitist tone and character, as well as use strong language (e.g. the sitting president François Hollande's is criticized for his recurrent powerlessness and his complete submission to Germany); (4) they suggest popular and simple measures (e.g. an increase of modest incomes pensions as well as protectionist policies and France's exit from the EU and (5) celebrate a folk community of patriots (e.g. 'all patriots attached to France's greatness').

In contrast to these most liked articles, articles about a specific topic or policy, mainly written by the old elites, are less 'Liked'. For example, an article by Jean Marie Le Pen entitled 'Because I refuse to surrender to the Brussels dictators, who want to impose on France a type of ultra-liberal society [ ... ] I support the French notaries' fails in popularity. The article talks about a niche topic, lacks background information to contextualize itself, does not address the French population as a whole but only a very small portion of it and does not link the notarial profession to any greater concern.

Finally, a multiple regression analysis confirmed that the articles by the new elites are more popular. In the model, we included all 355 press releases previously analysed. Our dependent variable was the number of Likes per press release. Our independent variables were dummy variables for Marion Maréchal Le Pen and for the new elites, with the old elites serving as the reference category. As control variables we included the number of words per article, and dummy variables for 2014 and 2015, with 2013 serving as the reference category (Table 3 ). 
The regression model demonstrates that the articles posted by the new party elite outperform, in terms of popular appreciation, those by the new elite even when controlling for the effect of time. In other words, the clear gap in the estimated number of Likes between the two types of party elite $(\Delta=1797)$ is far from being a compositional effect of the growing popularity of the Facebook page over time, with the average number of Likes per post rising from 1182 in 2013 to 1908 in 2015. On the contrary, it reflects an objective success of the 'new' populist discourse by Marine Le Pen and her party allies.

\section{Conclusion}

In this article, we have first described the FN's new political discourse, which effectively reframes the FN leitmotif immigration and uses populist tactics. While the FN certainly uses a more 'acceptable' rhetoric, the party has not become more mainstream. Rather, the FN's main propositions - be they the national preference, its strong anti-immigration platform or its tough measures on security - have remained essentially the same. What has changed is the populist undertone and character which the FN uses to package its propositions. Among other things, by using welfare chauvinism, charismatic leadership, a simple and emotional rhetoric, and anti-elitism, the FN has become the prototypical right-wing populist party.

Second, through an assessment of supporters' approval of FN Facebook postings, we have illustrated that the new style and repackaging of the FN's discourse resonate well with supporters and potential sympathizers (e.g. representatives of this new image received more than three times as many 'Likes' for their postings and articles than the old elites did for their postings). Hence, there is evidence that in the mid-2010s - a time of (multiple) crises (e.g. economic, identity and political) - a populist strategy, which emphasizes the woes of the working and lower-middle classes, adopts anti-European, anti-elitist and anti-neoliberal positions, stresses nationalism and rejects immigration within a broad republican framework tends to be endorsed by quite a large part of the population (see also Kriesi et al., 2008).

Through its activism on social platforms and, even more so its ideological reorientation, the FN has diversified its support base. Certainly, the use of a populist and republican rhetoric, the reframing of its anti-immigrant message, as well as its younger and more dynamic public image have increased the FN's vote base; in contrast to 20 or 30 years ago, the FN now attracts as many women as men (Mayer, 2013), and it is increasingly popular among young people (Arzheimer, 2012). With regard to the future of FN support and activism, we do not want to make any far-reaching claims. However, on consideration of the party's recent support, it is probably safe to say that a slight change in the party's discourse has had a large influence on the demand for action in the FN. The policies and solutions which the new FN proposes resonate well with an electorate and a population that have lived through several years of economic, political and identity crises and are disappointed with the mainstream parties. There is no reason to assume that this renewed support will wane unless conditions on the ground change rather drastically.

\section{Funding}

The author(s) received no financial support for the research, authorship and/or publication of this article. 


\section{Notes}

1. TNS-Sofres http://www.tns-sofres.com/_assets/files/2012.01.13-lepen.pdf and http://www. tns-sofres.com/_assets/files/2012.06.01-fn.pdf.

2. See also Krastev, 2007: 57 and Liang, 2007:3-6, for a more extensive description of populism.

3. Le Front National (2007) Élection Présidentielle 2007: Programme. Available at: http://ipolitique.free.fr/francepolitique/lepen2007.pdf (accessed 5 October 2014) and Le Front National (2012) Le Projet du Front National. Available at: http://www.frontnational.com/le-projet-demarine-le-pen/ (accessed 21 March 2015).

4. UMPS is a catch word which the FN uses to decry the elites of the mainstream centre-right party (the Union for Popular Movement, labelled UMP) and the mainstream centre-left party (the Socialist Party, labelled PS). According to FN discourse, both parties are characterized by the same corrupt elites and policies.

5. In more detail, we searched for the following verbal indicators of populism: Trahison (Trahi, Trahie, Trahir, Trahis, Trahison, Trahisons, Trahissent, Trahit, Traites, Traitre), Elites (Elites, Elite), Je (Je, Moi, Mon), Peuple (Peuple, Peuples), Nous (Nous, Nos, Notre), Corruption (Corrompu, Corruption), Front_National (Fn, Front_National, Front), Francais (Francais, France) and UMPS (Umps).

\section{References}

Aalberg T, Esser F and Reinemann C, et al. (eds) (2016) Populist Political Communication in Europe. New York: Routledge.

Abts K and Rummens S (2007) Populism versus democracy. Political Studies 55(2): 405-424.

Albertazzi D and McDonnell D (2008) Introduction: The sceptre and the spectre. In: Albertazzi D and McDonnell D (eds) Twenty-First Century Populism: The Spectre of Western European Democracy. Basingstoke: Palgrave Macmillan, pp. 1-11.

Alduy C and Wahnich S (2015) Marine Le Pen prise aux mots: Décryptage du nouveau discours frontiste [Marine Le Pen in her own words: Decrypting the new FN discourse]. Paris: Seuil.

Almeida D (2013) Towards a post-radical Front National? Patterns of ideological change and dediabolisation on the French Radical right. Nottingham French Studies 52(2): 167-176.

Alvares C and Dahlgren P (2016) Populism, extremism and media: Mapping an uncertain terrain. European Journal of Communication 31(1): 46-57.

Arzheimer K (2012) Electoral sociology: Who votes for the extreme right and why - And when? In: Uwe B and Moreau P (eds) The Extreme Right in Europe: Current Trends and Perspectives. Göttingen: Vendenhoeck \& Ruprecht, pp. 35-50.

Atton C (2006) Far-right media on the internet: Culture, discourse and power. New Media \& Society 8(4): 573-587.

Balent M (2012) Le Monde Selon Marine: La Politique International du Front National [The World According to Marine: The International Politics of the National Front]. Paris: Armand Colin.

Bariller D and Timmermans F (1993) 20 ans au Front: L'Histoire vraie du Front National [20 years of the Front: A real History of the National Front]. Paris: Éditions Nationales.

Barisione M (2016) Leadership, political. In: Mazzoleni G, Barnhurst K, Ikeda K and et al. (eds) International Encyclopedia of Political Communication. Malden, MA: Wiley-Blackwell, pp. 636-648.

Bartlett J, Birdwell J and Littler M (2011) The New Face of Digital Populism. London: Demos.

Benford RD and Snow DA (2000) Framing processes and social movements: An overview and assessment. Annual Review of Sociology 26: 611-639.

Betz H-G and Immerfall S (1998) The New Politics of the Right: Neo-populist Parties and Movements in Established Democracies. Basingstoke: Palgrave Macmillan. 
Bizeul D (2003) Avec ceux du FN: Un sociologue au Front national [With the Members of the FN: A sociology of the National Front]. Paris: La Découverte.

Bojadjian J (2015). Les Usages Frontistes du Web The FN's Web Usage. In: Crépon S., Dézé A. and Mayer N. (eds) IN Les Faux Semblants Du Front National: Sociologie d'un Parti Politique [The Pretences of the National Front: Sociology of a Political Party]. Paris: Sciences Po Presses.

Bos L and Brants K (2014) Populist rhetoric in politics and media: A longitudinal study of the Netherlands. European Journal of Communication 29(6): 703-719.

Bos L, Van der Brug W and De Vreese CH (2011) How the media shape perceptions of right-wing populist leaders. Political Communication 28: 182-206.

Bratten LC (2005) Online zealotry: la France du peuple virtuel [Online Zealorty: the France of the Online Users]. New Media \& Society 7(4): 517-532.

Burscher B, Van Spanje J, Claes H, et al. (2015) Owning the issues of crime and immigration: The relation between immigration and crime news and anti-immigrant voting in 11 countries. Electoral Studies 38: 59-69.

Canovan M (1999) Trust the people! Populism and the two faces of democracy. Political Studies 47(1): 2-16.

Ceron A, Curini L and Iacus SM (2014) Every tweet counts? How sentiment analysis of social media can improve our knowledge of citizens' political preferences with an application to Italy and France. New Media \& Society 16(2): 340-358.

Crépon S (2012) Enquête au coeur du nouveau Front national [Inivestigation in the Heart of the new National Front]. Paris: Nouveau Monde.

Dahlgren P (2013) The Political Web: Media, Participation and Alternative Democracy. Basingstoke: Palgrave Macmillan.

DeClair EG (1999) Politics on the Fringe: The People, Policies and Organization of the French National Front. Durham, NC: Duke University Press Books.

Della Posta DJ (2013) Immigration and the Front National: Competitive threat, intergroup contact, or both? Social Forces 92(1): 249-273.

Dézé A (2011) 'Un parti « virtuel »? Le front national au prisme de son site internet' [A "virtual" party? The National Front through the lens of its website]. In: Greffet F (ed.) In Continuerlalutte.com: les partis politiques sur le web [Continuethefight.com: Political Parties on the Web]. Paris: Presses de la FNSP, pp. 139-152.

Dézé A (2012) Le Front national: à la conquête du pouvoir? [The National Front: Conquering the Power?] Paris: Armand Colin.

Eatwell R (2000) The rebirth of the extreme right in Western Europe. Parliamentary Affairs 53(3): $407-425$.

Elinas A (2014) The Media and the Far Right in Western Europe: Playing the Nationalist Card. Cambridge: Cambridge University Press.

Hainsworth P (2008) The Extreme Right in Western Europe. New York: Routledge.

Hameleers M, Bos L and De Vreese CH (2016) "They did it": The effects of emotionalized blame attribution in populist communication. Communication Research. Epub ahead of print 2 June. DOI: $10.1177 / 0093650216644026$.

Hewlett N (2012) Voting in the shadow of the crisis: The French Presidential and Parliamentary elections 2012. Modern \& Contemporary France 20(4): 160-178.

Jagers J and Walgrave S (2007) Populism as political communication style: An empirical study of political parties discourse in Belgium. European Journal of Political Research 46: 319-345.

Karpf D (2012) The MoveOn Effect: The Unexpected Transformation of American Political Advocacy. New York: Oxford University Press. 
Kitschelt H with McGann AJ (1995) Radical Right in Western Europe: A Comparative Analysis. Ann Arbor, MI: University of Michigan Press.

Klandermans B (1997) The Social Psychology of Protest. Oxford: Wiley-Blackwell.

Klandermans B (2004) The demand and supply of participation: Social psychological correlates of participation in social movements. In: Snow DA, Soule SA and Kriesi H (eds) The Blackwell Companion of Social Movements. Oxford: Blackwell, pp. 360-379.

Klandermans B (2013) Extreme right activists: Recruitment and experiences. In: Von Mering S and McCarty TW (eds) Right Wind Radicalism Today: Perspectives from Europe and the US. London: Routledge, pp. 60-84.

Kling A (2012) FN... Tout ça pour ça! La très étonnante évolution du Front National [All for that: The very strange evolution of the National Front]. Strasbourg: Éditions Mithra.

Krämer B (2014) Media populism: A conceptual clarification and some theses on its effects. Communication Theory 24(1): 42-60.

Krastev I (2007) Is East-Central Europe backsliding? The strange death of the liberal consensus. Journal of Democracy 18(4): 56-63.

Kriesi H, Grande E, Romain L, et al. (2008) West European Politics in the Age of Globalization. Cambridge: Cambridge University Press.

Le Figaro (2014) «Le FN aurait doublé son nombre d'adhérents depuis 2012 » [The National Front has likely doubled its membership since 2012]. Available at: http://www.lefigaro.fr/ politique/le-scan/coulisses/2014/10/31/25006-20141031ARTFIG00061-le-fn-aurait-doubleson-nombre-d-adherents-depuis-2012.php?pagination=14 (accessed 3 November 2014).

Le Goff J-P (2011) Le syndrome du Front national [The National Front Syndrome]. Le Débat 166(4): 53-62.

Liang CS (2007) Europe for the Europeans: The foreign and security policy of the populist radical right. In: Liang CS (ed.) Europe for Europeans. Farnham: Ashgate Publishing Limited, pp. $1-31$.

Mayer N (2013) From Jean-Marie to Marine Le Pen: Electoral change on the far right. Parliamentary Affairs 66(1): 160-178.

Mazzoleni G (2003) The media and the growth of neo-populism in contemporary democracies. In: Mazzoleni G, Stewart J and Horsfield B (eds) The Media and Neo-Populism: A Contemporary Comparative Analysis. Westport, CT: Praeger, pp. 1-21.

Mudde C (2007) Populist Radical Right Parties in Europe. Cambridge: Cambridge University Press.

Mudde C and Kaltwasser CR (2014) Populism and political leadership. In: Rhodes RAW and 't Hart P (eds) Oxford Handbook on Political Leadership. Oxford: Oxford University Press, pp. 376-388.

Newman BI (ed.) (1999) Handbook of Political Marketing. London: SAGE.

Plasser F and Ulram PA (2003) Striking a responsive chord: Mass media and right-wing populism in Austria. In: Mazzoleni G, Stewart J and Horsfield B (eds) The Media and Neo-Populism. Westport, CT: Praeger, pp. 21-43.

Rooduijin M and Pauwels T (2011) Measuring populism: Comparing two methods of content analysis. West European Politics 34(6): 1272-1283.

Rooduijn M, De Lange SL and Van der Brug W (2014) A populist Zeitgeist? Programmatic contagion by populist parties in Western Europe. Party Politics 20(4): 563-575.

Schumpeter JA (1942) Socialism, Capitalism and Democracy. New York: Harper \& Brothers.

Shields J (2013) Marine Le Pen and the 'New' FN: A change of style of or substance? Parliamentary Affairs 66(1): 179-196.

Stockemer D (2014) Who are the members of the French National Front? Evidence from interview research. French Politics 12(1): 36-58. 
Taggart PA (2000) Populism. Buckingham: Open University Press.

Van Stekelenburg J and Klandermans B (2007) Individuals in movements: A social psychology of contention. In: Klandermans B and Roggeband C (eds) Handbook of Social Movements across Disciplines. London: Springer, pp. 157-204.

Von Mering S and McCarty TW (2013) Right-Wind Radicalism Today: Perspectives from Europe and the US. London: Routledge.

Weber M (1968 [1922]) Economy and Society [Wirtschaft und Gesellschaft]. New York: Bedminster Press. 